\title{
Catalytic Epoxidation of Limonene
}

\author{
E. Herrero, S. Casuscelli, J. Fernandez, C. Poncio, M. Rueda and O. Oyola \\ CITeQ, Universidad Tecnológica Nacional, Facultad Regional Córdoba, C.C.36, 5016 Córdoba, Ar- \\ gentina
}

Tel: 0351-4690585, E-mail: eherrero@sa.frc.utn.edu.ar

\begin{abstract}
The epoxidation of limonene with hidrogen peroxide was studied over zeolite Tibeta (a large pore material) and heteropoly acids on carbono and alumina supported. $\mathrm{PW}_{11} / \mathrm{C}$ was catalyst the best tested.
\end{abstract}

\section{Introduction}

In the last years, the increase in environmental restrictions lead to the search for new oxydant systems to replace the traditionals in order to avoid the generation of polluting effluents.

The terpenes containing oxygen are very important to be used in the fragrances production; in our country we have great quantities of limonene and thus we studied its oxydation to 1,2-epoxilimonene using a heterogeneous catalysts system.

In a previous paper the pillared clays from mixed oligomers of $\mathrm{Si}-\mathrm{Ti}$ [1] were studied, in this paper the results using supported heteropolyacids (HPA) an zeolites Ti-beta are shown.

\section{Experimental}

The HPA were prepared from phosphomolybdic acid (PMA) and tunstophosphoric acid (TPA) and then impregnated on alumina (A) or carbon (C) to fill the pores with solution in ethanol-water [2]. $\mathrm{PW}_{11}$ refers to a lacunar phase supported on $\mathrm{C}$. Ti-beta zeolite (Ti- $\beta$ ) was prepared according to [3].

The reactions were run in a batch type glass reactor with vigorous stirring and at $343^{\circ} \mathrm{K}$, the rate limonene $/ \mathrm{H}_{2} \mathrm{O}_{2}(35 \%)=4$ and $100 \mathrm{mg}$ of catalysts and acetonitrile as solvent; the reaction was followed by taking samples at different times and analyzing them by GLC, the remanent $\mathrm{H}_{2} \mathrm{O}_{2}$ was determined by iodometric titration. The reaction products were identified by comparation with chromatographic authentic samples and mass spectroscopy.

\section{Results and Discussion}

Limonene and $\mathrm{H}_{2} \mathrm{O}_{2}$ conversion and products selectivity at time on strem 7 hours, are shown in the next table. 


\begin{tabular}{|c|c|c|c|c|c|c|}
\hline \multirow{2}{*}{$\begin{array}{c}\text { CATALYSTS } \\
(\text { mmoles HPA/g })\end{array}$} & \multicolumn{2}{|c|}{ CONVERSION } & \multicolumn{4}{c|}{ SELECTIVITY } \\
\cline { 2 - 7 } & $\%$ max. & $\mathrm{H}_{2} \mathrm{O}_{2}$ & $\mathrm{H}_{2} \mathrm{O}_{2}$ & Epoxide & Cetones & Others \\
\hline TPA/A $(1.120)$ & 33,85 & 54,93 & 61,63 & 31,20 & 42,88 & 25,92 \\
\hline TPA/C $(0,855)$ & 13,03 & 33,92 & 38,41 & 22,95 & 41,49 & 35,56 \\
\hline MPA/A (1.280) & 34,62 & 65,36 & 52,96 & 36,89 & 33,86 & 29,25 \\
\hline MPA/C $(0,649)$ & 22,35 & 33,46 & 66,80 & 24,28 & 32,78 & 42,94 \\
\hline PW $_{11} / \mathrm{C}(0,820)$ & 38,22 & 71,58 & 53,40 & 58,74 & 30,23 & 11,04 \\
\hline $\mathrm{Ti}^{-} \beta\left(2,6 \% \mathrm{TiO}_{2}\right)$ & 46,21 & 71,51 & 63,62 & 22,94 & 54,60 & 23,86 \\
\hline
\end{tabular}

We can observe that supported HPA on A show a higher conversion and selectivity to the epoxide than the supported on $\mathrm{C}$, which are more selective to other products (glycols and acid catalysis products), owing to a lower interaction between HPA and support. The catalyst with higher activity is Ti- $\beta$ but the more selective is the lacunar phase $\mathrm{PW}_{11} / \mathrm{C}$, with high yield of epoxide derivative, because this phase has a vacancy compared with Keggin structure, whic is active for oxydation reactions.

Acknowledgements: The authors are grateful to Hernan Gabeta for experimental collaboration and financial support from CONICOR (project NO 4230/97).

\section{References and Notes}

1. Herrero, E.R.; Casuscelli, S.G.; Nievas, M.L.; Ricaud, J. XI SINAQO (1997), Actas QOS-56.

2. Vazquez, P.; Pizzio, L.; Blanco, M.; Cáceres, C. XVI Simp.Ib.de Catál. (1998), Actas II, 1461 y III, 2123.

3. Blasco, T. et al. J. Phys. Chem. B 1998, 102, 75. 